\title{
Gentleman Personality and the Improvement of College Students' Quality
}

\author{
Preng Nien $\mathrm{Hu}$ \\ Department of Public Management \\ Nanfang College \\ Sun Yat-sen University \\ Guangdong, China
}

\begin{abstract}
Colleges and universities are the cradle to cultivate students and the base to bring up backbone of the country. University education includes not only the teaching of professional knowledge by teachers but also the thorough understanding of ethical practice, making students experience the combination of knowledge and morality, so as to shape the perfect personality. On the basis of the connotation of the traditional culture in our country, the personality can be increasingly mature and easy-going through the acculturation in learning. The noble and elegant cultural ethos and moral cultivation of intellectuals can be showed through gestures and expressions, to influence the overall social environment and achieve the effects of correcting the unhealthy social ways and customs and civilizing the people.
\end{abstract}

Keywords-acculturation; higher education; education of teachers' morality; gentleman personality

\section{INTRODUCTION}

Education is project of vital and lasting importance and the basis for the founding of a state. The universities are to foster top-level talents for the country, including: train talents, develop the science and directly serve the society. It exerts people's instinct, depends on their personality and improves the reason, in order to cultivate "a modest, self-disciplined gentleman" with noble characters, wide range of learning, noble personality glamour, elegant manners as well as external and internal cultivation, achieving the purpose of "combining the favorite with the strong points". They have independent and complete thinking, sound personality and rich professional skills and will dedicate what they have learnt to the country and serve the people.

They have been regarded as the intellectuals with lofty ideals and aspiration, having received higher education. However, nowadays, influenced by the western material civilization, the university education attaches little importance to the development and inheritance of the traditional culture in our country. Instead, they advocate the Occidentalism, resulting in the declination of college students' moral idea. Therefore, the firm and persistent noble personality and manner can be cultivated through the edification of solid moral education, in order to improve college students' quality. This paper analyzes and researches from the implementation of the gentleman personality and the improvement of college students' quality.

\section{DEFINITIONS OF GENTLEMAN AND GENTLEMAN PERSONALITY}

The word "gentleman" is widely seen in the ancient books and records before Qin Dynasty, referring to "the son of the king" with important political status. Afterwards, the Confucius gave the meaning of morality to the word "gentleman". It has the meaning of morality since then and is used in ancient books like the Book of Changes, the Book of Songs and the Book of History. For example, the Book of Changes, Qian records, "gentleman should constantly strive to become stronger around the clock and be cautious at night, so that he can get rid of disasters." The Book of Songs, Zhounan, Guanju records, "A lad would like to woo, a lass with nice and pretty look". The Book of History, Yushu, Strategy of Yu the Great records, "gentlemen with lofty character cannot display their abilities and have no official position but the unaccomplished vile characters occupy important position." The gentlemen have both ability and political integrity, just like the Confucius said, "The wise will not be confused, the benevolent will not be worried and the brave will not be afraid", showing the undaunted spirit.

In modern sense, the gentleman personality should be owned by a good people; his power comes from his personality and heart. He is satisfied about himself. Except for the selfcultivation, he shows the unruffled and natural temperament and conforms to the development of things; reflects on himself and feels unregretful and unashamed. These people have the gentleman personality. The realization depends on their resolution and power.

\section{Cultivation OF COllege Students’ Noble CHARACTER}

Higher education can foster top-level talents, lay the foundation of professional and general knowledge and promote us to understand the truth of individual behaviorism, especially train the pure and noble attitude, the firm and persistent as well as brave spirit, develop the elegant sentiment. College students can obtain the broad knowledge and experience like "The tolerant can tolerate others; people with 
profound moral character can assume heavy responsibilities". They can understand what Guanzi said, "We should not try impossible things, not pursue the unavailable things, not occupy the unendurable position and not implement the unrepeatable policies", and the truth said by Mr. Gao Daochun, "the people failing to conduct himself with dignity will invite humiliation, the people without awe-stricken heart will attract the source of the disaster, the humble people will benefit and the people not considering himself always right will know more". In the world with decadent manners and morals of the time, people care for nothing but lust. People should take the faith of self-cultivation and perseverance and not excessively court fame and fortune. Instead, they should keep the humble, quiet and self-disciplined attitude and cultivate themselves with great concentration, comprehending the idea of words said by Zeng Guofan, "People will have a strong body with a solemn and quiet mind; people will feel pleasant and peaceful if he can set strict demands on himself; people will have physical and mental pleasure if he pursue the kindheartedness and justice constantly; people will be admired by the god if he learns and works diligently". Therefore, it is necessary to read up the classic works full of wisdom of sages at all times and in all over the world, and then reflect on, experience and practice, such as the following old maxims:

1. The relationship between gentlemen resembles clean water; the relationship between vile characters resembles sweet wine. Gentlemen make friends to assist the cultivation of their culture and kindheartedness, so that they can be virtuous person. Vile characters often harm others to benefit themselves and forget friendship for profit, so that they cease to be faithful. (The Book of Rites)

2. The gentlemen take delight in the poverty, but the vile characters will act wildly against law and public opinion if they are poor. (The Analects of Confucius)

3. The gentlemen do what they can and listen to the fate, but vile characters take the risk of improperly requesting inordinate profit. (The Doctrine of Mean)

4. The gentlemen take things as they are and endeavor to do what they should do. (The Book of Rites)

5. A person will not be beneficent if he is malicious for a moment; not loyal if he is greedy for a moment; not courteous if he is arrogant for a moment; not wise if he is deceitful for a moment, so that the valuable point of gentlemen is that he can set strict demands on himself when staying alone. (Tang Bin)

6. The gentlemen in ancient times set strict and comprehensive demands on themselves but treat others with tolerance. (Han $\mathrm{Yu}$ )

7. The gentlemen are often modest instead of arrogant; they treat others with patience and modesty instead of being supercilious. (Zeng Guofan)

8. The gentlemen are cautious when staying in the place where people cannot see; they are afraid of having fault in the place where people cannot listen. (The Doctrine of Mean)

9. The sages will not behave improperly, not hate people who deny them, not ask others to praise them but cultivate morality. (Huainanzi)
10. The gentlemen are ashamed of not being cultured instead of being slandered; ashamed of not being credible instead of being suspected. (Xunzi)

11. The gentlemen have benevolence and courtliness in their heart. (Menci)

12. The gentlemen will not forgive themselves and blame others because of their different political views. (Hou Fangyu, the Letter to Ruan Guanglu).

The higher education advocates and implements the practical and surefooted teaching methods, in order to train students with marvelous tolerance, profound and lasting knowledge, self-restraint and culture. We should use the knowledge to cultivate the temperament and use law and discipline rite to restrain the body and mind. Get close to good teachers and helpful friends, get away from blinkered and evil people and adhere to the principles that people should be respectful and polite, conform to moral standard and do not behave beyond the moral rule; the behavior conforms to the righteousness and people should not consider themselves no ordinary being; people should be honest and upright in front of the profit, don't conceal their mistakes and improper behaviors; people have consciousness of shame, neither associate with an evil person nor do things violating the moral rule. A person good at learning, will become a wise man; a person tries his best will a benevolent man; a person always have "honor" in mind will be a brave man. So we will enlighten students to keep away from the villain (because evil is from the injudicial characters and the small tolerance), and to create a real and independent personality, a unique individuality; students must have their advantages and weaknesses, but they should be frank, not make moral camouflage, but combine social ethics and the code of conduct to show their noble character and professional knowledge as intellectuals (a person should have unyielding character but not arrogance); they should have a rational choice under the guidance, and when dealing with problems, they should have strict requirements on themselves but be generous for others, really achieving the state of "not flurried or troubled". Once developing a strong and resolute personality, they should have great invisible influence on others. Many ancient sayings all describe the significance of influence of personality, which is representation of gentleman's personality.

As recorded in the Learning Cases of the Song and Yuan Dynasties, "only by perusing the sage's diction, deep thinking, and pondering over day and night, can scholars develop their ability and knowledge and gradually become wise and cultivate their virtue. For a long time, students may not have vague thinking or lazy action, but they will be active and diligent in their study, dedicated to academic learning and practice, and strive for their ideal goals in life. After entering into the community, they will be able to respect civilization and justice, follow disciplines and law, fulfill their responsibilities, heartily serve and repay the society and benefit the public. Therefore, this pattern has reflected the principle that "the purpose of university is to promote the integrity of character, to abandon the old for the new, and to make people achieve the most perfect state". 


\section{The Focus of COLlege Teachers to Train STUDENTS}

Education is the principle of a nation to keep its spirit and culture and also the base to consolidate a long life. Therefore, the success or failure of education is closely related to the rise and fall of a nation. Particularly, to cultivate the gentleman-like personality of students, college teachers should work from the three aspects: improvement of academic standards, promotion of educational occupation, enhancement of vocational knowledge and skills and teacher ethics.

1. In the academic level, we not only should fully master the knowledge of the subject engaged from the academic front, but also grasp the academic front and new trends; not only pass scientific knowledge, but assume the task of new scientific knowledge innovation. For the improvement of college students' quality, we can not always settle for teaching traditional science knowledge, but also must continue to introduce new knowledge and ideas as well as opinion on knowledge of related disciplines, and further digestion them. Therefore, the deep and broad foundational theory and wide cross-disciplinary knowledge are necessary for the development of college teachers.

2. In the professional knowledge and skills, teachers are experts and also scholars, who should pass the inherent traditional virtues of China, and the content includes intellectual education (knowledge and skills training, involving wisdom, faith, benevolence, braveness, strictness), moral education (improvement of moral character), sports (spiritual and physical enhancement), group education (development of united, friendly and cooperative characters). To become a citizen of an independent and free modern country, we must accept these four items of education, and gradually build an excellent team with ideal and belief, moral sentiments, solid knowledge, and humanity, while teacher ethics is the most important for building such a team. The enlightenment of teacher ethics enable students to have mature mind and solid learning foundation, and further bring the effect of enculturation and improve the quality of culture, briefly explained as follows:

1) The internal and external practice in the moral scope for merging and integration of teaching and leaning: whether for moral character, bearing, appearance or determination, we must train it from the spiritual cultivation (called science of life). Such spiritual cultivation is based on the philosophy of our country. Our traditional philosophical thought affirms that everything in the universe is harmonious and mutually complementary, which is purposed to explore the theory of "studying things, cultivating morality and practicing virtue". Making it balanced and unified with the practice out of knowledge (called the Practical Confucianism) and blending the theory of interior and exterior into the teaching, is enough to exert a subtle influence on students.

2) To teach the idea of keeping justice and removing appetency: judge all matters according to justice, moral and conscience. It is righteous that all things are practiced in accordance with logic and conscience and legal norms and in the light of normal reason and common sense.
3) The expatiation and development of Wang Yangming's saying: a person has determined to be a gentleman, should be engaged in this learning, and if not diligent, his ambition will not be achieved. And as described in the History of the Ming Dynasty - Zhou Xin Biography: a gentleman has three pities: the first is not studying in the life, the second is idling in the day, the third is failing for the life, which are important. in addition, it is recorded in Confucian Analects: a gentleman is not committed to food and living environment, diligently works and carefully speaks, and also take the initiative to ask for corrections to the people with noble aspirations, so he can be called a scholar. Through analysis and discussion of these sayings, we guide students to make comprehension and practice of it.

4) Require students to check their thinking and behavior in the course of study and daily life; to be selfless and try to help others; take national benefits first, protect the national honor; keep plain and honest, make self-reflection on their mind, concept, action, life, value and work; improve study and morals, not complain without cause, understand the philosophy and obtain the true meaning of life through learning of usual knowledge. Correct own attitude and behavior, have extraordinary ability and insight, make a clear distinction between right and wrong, have the aptness of gentleman, and also have strong patience and unshakable spirit, rather than short sight, opportunistic speculation and cause trouble and disturbance for short happiness. If achieving the ambition, to be willing to contribution and benefit the people; and if failing, to be tolerant and generous, considering for others, which is a ambit of accepting every challenge in life and not yielding to the failure. Learn Yi Zhen's truth of life, Da Yu's diligence and Mo Zi's thrift, Lao Zhuang's stillness and emptiness, to achieve the great ability and tolerance through self-cultivation.

5) Teach students to establish ambition: A person has enough ambition, can reach the place no matter how far it is, and even at the end of the sea, it can not be limited; a person has enough ambition, can break the barrier no matter how strong it is, and even for the elite armor, it can not be stopped. So students should have such faith and will. Keep upright mind, speech and behavior; promote self-cultivation, highlight the perfect moral character, examine own thoughts and conduct all days till achieving perfection.; determine the goal, really and unremittingly try for it to make success and realize the goal, as described by the ancient that the spiritual values will be reconstructed for the society, the meaning of life established for the people, the learning system of the Saint inherited for the future generations and the foundation opened up for a permanent peace.

In view of this, Zeng Guofan once said: "The honesty or violence of the society is often closely related to the values of the highest leaders, and the power of social progress usually depends on the drive of pioneers for shaping and diffusion of the new mode of thinking and the values". Thus, we can see students are the backbone of society, their cultivation of knowledge and moral character is valued, which has the role of leading the social ethos, with great influence. if it can develop in a positive direction, it will enlighten the people. Therefore, college education is to explore professional and profound knowledge and also to cultivate the four- ethics personality, 
effectively improving the humanistic quality and making the society develop in a favorable way.

\section{CONCLUSION}

In memory of the 2565 anniversary of the Confucius' birthday, on the international academic seminar, general secretary $\mathrm{Xi}$ Jinping says, "The abundant philosophical thought, humanistic spirit, enlightenment thought and moral idea in the excellent traditional Chinese culture can provide beneficial enlightenment for people to know and change the world, rule the state and deal with politics and for the moral construction". Doing in-depth research on its historical value and the contemporary inheritance has significance in carrying forward the excellent Chinese culture and constructing the advanced cultures of socialism with Chinese characteristics.

The traditional Chinese gentleman culture is the typical representative of the excellent traditional culture with the unique Chinese characteristics. Therefore, one of the important purposes of university education is to foster the sound traditional gentleman culture. Especially in the process of acculturation, it is necessary to base on the traditional culture of our country, and integrate it in the university education, combining with the connotation of professional knowledge and truly realizing the integration of theory and practice, traditional culture and the applied science. In this way, the college students with socialist core values with Chinese characteristics (prosperity, democracy, civilization, harmony, freedom, and equality, and justice, rule of law, patriotism, dedication, integrity and friendliness) can be cultivated. They will develop the personal characteristics with profound cultural deposits. Their humanistic quality will also increase with the enhancement of professional knowledge. Therefore, the tangible (intangible) education edifies the gentleman personality with noble character. They will produce copious positive energy after entering the society, influencing the social ethos and fashion, causing remarkable effects. This force can change the bad social ethos. The realization of the overall effect depends on the joint efforts of all university teachers and the concrete implementation.

\section{REFERENCES}

[1] Pu Jialin, Dictionary of Chinese Proverbs [M], the Far East Book Company, 1976

[2] Xia Jianwen. Research on the Carrier of Teachers' Moral Education Based on the Perspectives of the Cultivation and Practice of Socialist Core Values in Universities [J], Education Forum, 2016, 27(7): 34-35

[3] Lu Xiaozhong, editor-in-chief, Introduction to Higher Education [M], Higher Education Press, 2009

[4] Compiled by the Personnel Department of the Ministry of Education, Cultivation of Teachers' Professional Morality in Universities [M], Beijing Normal University Press, 2010

[5] See also http://baike.so.com/doc/5276789-5510902.html

[6] See also http://baike.so.com/doc/1722494-1820968.html 